\title{
Testosterone Mediates Seasonal Growth of the Song Control Nuclei in a Tropical Bird
}

\author{
Thomas W. Small a, b Eliot A. Brenowitz ${ }^{c, d}$ Winfried Wojtenek \\ Ignacio T. Moore ${ }^{a}$ \\ ${ }^{a}$ Department of Biological Sciences, Virginia Tech, Blacksburg, Va., ${ }^{b}$ Department of Biological Sciences, \\ University of Memphis, Memphis, Tenn., and Departments of ' $B$ Biology and d Psychology, University of

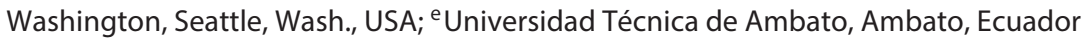

\section{Key Words}

Song $\cdot$ Neurogenesis $\cdot$ Neuroplasticity $\cdot$ Testosterone ·

Seasonality $\cdot$ Tropics

\begin{abstract}
In mid- to high-latitude songbirds, seasonal reproduction is stimulated by increasing day length accompanied by elevated plasma sex steroid levels, increased singing, and growth of the song control nuclei (SCN). Plasticity of the SCN and song behavior are primarily mediated by testosterone (T) and its metabolites in most species studied thus far. However, the majority of bird species are tropical and have less pronounced seasonal reproductive cycles. We have previously documented that equatorial rufous-collared sparrows (Zonotrichia capensis) exhibit seasonal neuroplasticity in the SCN. Manipulating T in these birds, however, did not alter singing behavior. In the current study, we investigated whether T mediates plasticity of the SCN in a similar manner to temperate songbirds. In the first experiment, we treated captive male birds with T or blank implants during the nonbreeding season. In a second experiment, we treated captive male birds with either blank implants, T-filled implants, $T$ with flutamide (FLU; an androgen receptor antagonist) or $\mathrm{T}$ with FLU and 1,4,6-androstatriene-3,17-dione (ATD; an es-
\end{abstract}

trogen synthesis inhibitor) during the breeding season. In both experiments, the volumes of the brain areas high vocal center (HVC), Area X, and robust nucleus of the arcopallium (RA) were measured along with singing behavior. In summary, T stimulated growth of HVC and RA, and the combined effect of FLU and ATD reversed this effect in HVC. Area X was not affected by $T$ treatment in either experiment. Neither Ttreated birds nor controls sang in captivity during either experiment. Together, these data indicate that T mediates seasonal changes in the HVC and RA of both tropical and higherlatitude bird species even if the environmental signals differ. However, unlike most higher-latitude songbirds, we found no evidence that motivation to sing or growth of Area $X$ are stimulated by $T$ under captive conditions.

(c) 2015 S. Karger AG, Basel

\section{Introduction}

The seasonal growth and regression of the avian song control nuclei ( $\mathrm{SCN}$ ) is one of the best-studied examples of adult neuroplasticity [Tramontin and Brenowitz, 2000]. The natural seasonal changes in both the size and structure of specific avian brain nuclei are the most pronounced among the vertebrates studied thus far [Bre-

\section{KARGER 125}

(c) 2015 S. Karger AG, Base

0006-8977/15/0862-0110\$39.50/0

E-Mail karger@karger.com

www.karger.com/bbe
Thomas W. Small

Department of Biological Sciences

University of Memphis, 3774 Walker Avenue

Memphis, TN 38152-3530 (USA)

E-Mail twsmall@memphis.edu 
nowitz et al., 2004; Fuchs and Flügge, 2014]. The song control system is made up of a series of interconnected forebrain nuclei that control learning and the expression of singing behavior. Among the best understood of these nuclei is the sensorimotor nucleus high vocal center (HVC), which sends afferent projections to both the premotor robust nucleus of the arcopallium (RA) and to the basal ganglia homologue Area X. In most species, the seasonal changes in the volume of these nuclei parallel changes in reproductive system activity and singing behavior [Brenowitz et al., 2004] suggesting a functional relationship between song system neuroplasticity and the reproductive system.

In many mid- to high-latitude breeding animals, the annual change in photoperiod regulates reproductive system activity [Dawson, 2003; Bradshaw and Holzapfel, 2007]. In birds, as day length increases in spring, the hypothalamic-pituitary-gonadal axis becomes active resulting in increased sex steroid release from the gonads [Dawson, 2008]. In males, elevated testosterone (T) modulates singing behavior, in part, by acting on the SCN. T can act through either androgen receptors in HVC or estrogen receptors, after local conversion to estrogen by the enzyme aromatase [Gahr, 2001; Brenowitz et al., 2004]. Androgen receptors are also present in RA and Area X of many species [Gahr and Metzdorf, 1997; Bernard et al., 1999; Kim et al., 2004; Wada et al., 2013], but the effect of $\mathrm{T}$ on their plasticity is indirectly mediated through HVC [Brenowitz et al., 2004; Meitzen et al., 2007]. When stimulated by T, HVC rapidly grows due largely to an increase in cell number, achieving maximal size within a week. RA and Area $\mathrm{X}$ growth is due to increases in neuron size and density, but not cell numbers, and growth lags behind HVC [Tramontin et al., 2000; Thompson and Brenowitz, 2005]. There is some evidence for nonsteroidal mediation of growth of the SCN [Bentley et al., 1999; Cassone et al., 2008], but the steroidal pathway is generally accepted as the primary mechanism mediating seasonal growth of the nuclei [Brenowitz, 2008].

The rufous-collared sparrow (Zonotrichia capensis) is a congener of the white-crowned sparrow (Z. leucophrys), which is an important model in the study of song system plasticity [Smith et al., 1997; Soma et al., 1999a; Robertson et al., 2014]. Song is an essential component of both territorial defense [Moore et al., 2004a; Addis et al., 2010] and courtship [Danner et al., 2011] in rufous-collared sparrows, and this species was the first tropical vertebrate shown to exhibit seasonal neuroplasticity [Moore et al., 2004c]. The growth of the rufous-collared sparrow SCN occurs during the early breeding seasons, concurrent

Testosterone and the Song System in a Tropical Bird with increased singing behavior, and is similar to that described in higher-latitude congeners that have been more extensively studied [e.g. Smith et al., 1997; Soma et al., 1999a; Robertson et al., 2014].

In equatorial populations of rufous-collared sparrows, reproduction correlates with the end of the rainy season [Moore and Wingfield, 2002; Moore et al., 2005] and is not associated with changes in day length [Moore et al., $2004 c, 2006]$. For example, in two equatorial populations located within $25 \mathrm{~km}$ of each other, individuals breed seasonally within each population, but the breeding seasons differ by 3 months between the populations [Moore et al., 2005]. At both sites, HVC, RA, and Area X were larger in breeding versus nonbreeding males despite differences in the timing of breeding. The asynchronous changes between the two populations, and the fact that these birds only experience a $\sim 3$-min annual shift in photoperiod (US Naval Observatory), strongly suggest that the photoperiod is not a significant regulator of the reproductive system or SCN size in these equatorial animals.

Similar to northern latitude species, at the beginning of the breeding season, the hypothalamic-pituitary-gonadal axis of rufous-collared sparrows increases expression of gonadotropin-releasing hormone I, the gonads develop, and plasma sex steroid levels are elevated to concentrations that are comparable with northern congeners [Moore et al., 2002, 2004b, 2006; Stevenson et al., 2012]. These changes accompany increased singing behavior and the growth of the SCN of males but not females [Stevenson et al., 2012]. This correlation between reproductive system activity, singing, and song system growth suggests a causal relationship between $\mathrm{T}$ and neuroplasticity similar to higher-latitude congeners.

However, many tropical birds do not exhibit the same behavioral and physiological responses to elevated plasma $\mathrm{T}$ as seen in northern latitude species [Stutchbury and Morton, 2001; Hau et al., 2008]. Male rufous-collared sparrows are more aggressive and only sing during the breeding season, but unlike many other birds, they do not increase $\mathrm{T}$ levels in conjunction with the higher aggressive behaviors caused by simulated territorial intrusions [Moore et al., 2004b; Wingfield et al., 2007; Goymann, 2009; Addis et al., 2010]. Supplementation with T during prebreeding does not increase aggressive behaviors, including singing [Moore et al., 2004b], and blocking T with the androgen receptor antagonist flutamide (FLU) and the aromatase enzyme inhibitor 1,4,6-androstatriene-3,17-dione (ATD) does not reduce aggressive behaviors [Moore et al., 2004a], suggesting that singing motivation associated with aggression is not altered by elevated 
$\mathrm{T}$. The uncertain role of $\mathrm{T}$ in singing behavior also raises questions concerning what role $\mathrm{T}$ plays in the regulation of SCN growth.

The equatorial rufous-collared sparrow system provides a unique opportunity to investigate if different environmental cues are translated into similar behaviors through conserved neuroendocrine pathways. More specifically, does T mediate changes in the SCN of these birds, as it does in higher latitude congeners, despite no known effect of $\mathrm{T}$ on singing behavior in free-living males? In two complementary experiments, we manipulated androgen action in rufous-collared sparrows living on the equator in Ecuador. In the first experiment, we predicted that implanting nonbreeding sparrows with $\mathrm{T}$ would stimulate growth of the song nuclei. In the second experiment, we predicted that blocking androgen action in captive T-treated birds would prevent growth of the nuclei. We found that, as predicted, $T$ activity is necessary for the growth of at least two out of the three nuclei that were measured, but $\mathrm{T}$ does not appear to facilitate increased singing behavior in captive males.

\section{Materials and Methods}

\section{Subjects}

For experiment 1 , adult male sparrows were passively caught in mist nets at dawn in and around Papallacta, Napo Province, Ecuador $\left(0^{\circ} 22.3^{\prime} \mathrm{S}, 78^{\circ} 8.2^{\prime} \mathrm{W}, 3,300\right.$ m elevation; May 25 to June 5, 2007; $\mathrm{n}=16)$. For experiment 2 , adult males were caught in and around Pintag, Pichincha Province $\left(0^{\circ} 22.7^{\prime} \mathrm{S}, 78^{\circ} 22.6^{\prime} \mathrm{W}, 2,900 \mathrm{~m}\right.$ elevation; September 13-23, 2008; $\mathrm{n}=24)$. Captures at both sites were conducted during their respective nonbreeding periods. While these two populations are only $25 \mathrm{~km}$ apart, breeding commonly occurs between September and December in Papallacta and late November to early March in Pintag, reflecting geographic differences in rain fall [Moore et al., 2005]. This difference in the timing of reproduction allowed for greater flexibility in coordinating hormone treatments during either the nonbreeding or breeding periods of the birds' source populations. To assess reproductive status at the time of capture, molt was scored, cloacal protuberance length (CP; an androgen-dependent secondary sexual characteristic) was measured, and the birds were laparotomized (see below), so testis development could be directly measured. At both sites, the birds were not molting, had undeveloped CPs $(<4 \mathrm{~mm})$ and had regressed testes ( $<2 \mathrm{~mm}$ diameter) when captured, indicating they were not in breeding condition and were unlikely to have bred in the previous month. All experiments and procedures were approved by the Virginia Tech Institutional Animal Care and Use Committee.

\section{Housing Conditions}

Birds in both experiments were transported to Quito, Pichincha Province, Ecuador $\left(0^{\circ} 8.7^{\prime} \mathrm{S}, 78^{\circ} 27.8^{\prime} \mathrm{W}, 2,900\right.$ m elevation $)$ on the day of capture and were individually housed in wire cages
$(33 \times 51 \times 51 \mathrm{~cm})$ in an outdoor aviary $(2.5 \times 2.5 \times 3 \mathrm{~m})$ with open sides and a translucent roof. The aviary was in a private walled in space with restricted access and activity in the space was limited to the experiment being conducted. Treatment and control birds were evenly distributed throughout the aviary. Birds were provided ad libitum water and food (Trill Canary Mix, Mars, Inc.) throughout both experiments.

\section{Implants}

Experiment 1. To investigate the effect of $\mathrm{T}$ on the growth of song nuclei, birds were either implanted with $\mathrm{T}$ (T-treated; $\mathrm{n}=8$ ) or received empty implants (controls; $\mathrm{n}=8$ ) for 21 days. After capture in Papallacta, birds were acclimated to the housing facility for 14-25 days (depending on capture date) prior to implantation (implantation occurred on experiment day 0 ). Three days prior to implantation (day -3), body mass (Pesola spring scale to nearest $0.1 \mathrm{~g}$ ), wing chord length (wing rule to nearest millimeter), CP length, and fat score (scale $0-3$ based on visual inspection of the furcular and abdominal regions) were measured in all birds and a $\sim 250$ - $\mu$ l blood sample was collected (see below). Also on day -3 , the birds were separated into T-treated or control groups balanced by body size and condition. On day 0 , the $\mathrm{T}$-treated birds received two 10 -mm T-filled subcutaneous silastic implants $(1.47 \mathrm{~mm}$ inner diameter; Dow Corning) along the left flank, and the control birds received two empty (control) silastic implants of the same size (see below for surgical details). Similar-sized implants were previously used in this species to elevate plasma $\mathrm{T}$ to high, physiologically relevant, breeding levels [Moore et al., 2004b]. On day 21 postimplantation, body mass, CP length, and fat score were measured and a second blood sample was collected and stored. The birds were given a terminal intramuscular injection of $7.5 \mathrm{mg}$ sodium pentobarbital and were transcardially perfused with $0.9 \%$ heparinized saline (150 IU/10 ml) followed by $10 \%$ neutral buffered formalin. Brains and testes were removed within 5 min of perfusion. Brains were postfixed in $10 \%$ formalin and were stored under refrigeration until delivery to the University of Washington (Seattle, Wash., USA). Postperfusion, the gonads were removed and testis diameter and lengths were measured (to $0.01 \mathrm{~mm}$ using digital calipers) and volume was calculated using the formula for ellipsoid cylinders $\left[4 / 3 \pi \times(0.5 \text { width })^{2} \times(0.5\right.$ length $\left.)\right]$. Experiment 1 (capture to tissue collection) occurred during the nonbreeding period in the subjects' source population (Papallacta).

Experiment 2. To determine whether T-induced growth of the song nuclei occurred through androgen and/or estrogen receptors, the birds were treated with androgen receptor antagonist FLU and/ or ATD, which inhibits the aromatase enzyme necessary for conversion of androgens to estrogens. After capture in Pintag, the birds were acclimated to the housing facility for 65-75 days prior to implantation. Three days prior to implantation (day -3$)$ a blood sample was collected for all birds and wing chord length, body mass, and fat scores were used to separate the birds into four groups ( $\mathrm{n}=6$ per group): $\mathrm{T}$ treated (T-treated), $\mathrm{T}$ with FLU (T+FLU), T with FLU and ATD (T+FLU+ATD), and controls. Due to limited facilities and birds, we did not include a T with ATD group. On day 0 , the T-treated birds received two $10-\mathrm{mm}$ T-filled and four empty silastic implants (one T-filled and two blanks along each flank). The T+FLU birds received two 10-mm T-filled, two 10-mm FLU-filled, and two empty silastic implants (one of each type along each flank). The T+FLU+ATD birds received two 10$\mathrm{mm}$ T-filled, two 10-mm FLU-filled, and two 10-mm ATD-filled 
silastic implants (one of each type along each flank). The controls received six empty $10-\mathrm{mm}$ silastic implants (three along each flank). Surgical sites were checked on days 2, 7, and 14. On day 27, body mass, CP length, and fat score were measured, a second blood sample was collected, the birds were perfused, and their brains were stored as previously described. The testes were measured as above and were also weighed using a digital scale. Three birds were removed from the study, one T+FLU and two T+FLU+ATD, due to a lack of healing at the site of implantation and their repeated loss of implants. The capture of subjects for experiment 2 and acclimation to the facilities occurred during the nonbreeding season in the source population (Pintag), but hormone treatment occurred during the early breeding season.

\section{Behavioral Observations}

During both experiments individual behavior was monitored on three separate days (expriment 1: days 4, 11, 18; experiment 2: days $6,16,25)$ starting within $30 \mathrm{~min}$ of dawn. Observations were conducted from behind a blind positioned $5 \mathrm{~m}$ either east or west of the aviary. Each of the two positions allowed for half of the birds in the aviary to be observed at one time (equal numbers of each treatment). When observations on one side were completed, observations on the other side were started 15 min after moving between the blinds to allow the birds to recover from the disturbance. Individuals on each side of the aviary were observed for singing rate for 24 min (experiment 1) or 36 min (experiment 2) totaling 48 and $132 \mathrm{~min}$ of observation time per day. Any singing was recorded and if it occurred on the side being observed, the individual singing could be noted. To quantify activity rate, two birds in adjacent cages were observed at the same time for two 3-min sessions each day. Activity level was quantified by the number times the bird hopped between one of three perches. Further, the aviary was located next to the researcher housing and work space, allowing for any singing that came from the aviary to be noted during the day.

\section{Surgical Techniques}

Prior to laparotomies or implantation, the birds were anesthetized with isofluorane inhalation, the surgical area was cleaned with $70 \%$ ethanol, and 5\% lidocaine ointment was applied topically to the area of incision. For laparotomies, a 2- to 3-mm incision was made between the last pair of ribs and the diameter of the left testis was measured to the nearest $0.5 \mathrm{~mm}$ using forceps and a ruler. For implantations, a 2- to $3-\mathrm{mm}$ incision was made in the skin above the last pair of ribs and the implants were inserted between the skin and the muscle. The incisions were sealed with surgical glue.

\section{Blood Sampling and T RIA}

Blood samples were collected from the alar wing vein into heparinized capillary tubes. Samples were stored on ice until later the same day when they were centrifuged, the plasma was separated, and the samples were frozen until they were assayed. For the assay, steroids were extracted from plasma using distilled dichloromethane and were purified and separated by chromatography using diatomaceous earth (Celite, Sigma). Concentrations of T were measured in duplicate by standard radioimmunoassay techniques [Moore et al., 2002] and T concentrations were corrected for individual extraction efficiency. The assay detection limit was $\sim 0.08$ $\mathrm{ng} / \mathrm{ml}$, and there were intra-assay variations of 7 and $8 \%$ (two assays) and interassay variations of $8 \%$.

Testosterone and the Song System in a Tropical Bird

\section{SCN Volume Analysis}

After extraction, the brains were cryoprotected in 30\% sucrose until they sank. They were then frozen on dry ice and stored in a $-80^{\circ} \mathrm{C}$ freezer. The brains were sectioned by microtome at $40 \mu \mathrm{m}$ in the coronal plane and every third section was Nissl stained. Song nuclei volumes were measured and calculated as described previously [Smith et al., 1995; Brenowitz et al., 1998; Tramontin et al., 1998]. Briefly, a magnified (46x) image of each stained section was projected onto paper, and the profiles of the telencephalic song nuclei HVC, RA, and Area X were traced. Traces were scanned into a computer, and the area was calculated using NIH Image software. The volume of each nucleus was calculated using the formula for a cone frustum over each measured profile area. To control for individual differences in overall brain volume, for each bird the song nucleus volumes were divided by the volume of the entire telencephalon [Tramontin et al., 2000]. Telencephalon volumes were calculated for one side of the brain by projecting a magnified $(14 \times)$ image of every sixth mounted section through the entire telencephalon. The volume for the one side of the telencephalon was calculated similar to the song nuclei calculations and was then doubled to estimate the total volume of the telencephalon. In the controls for experiment 1 , one individual's HVC volume and another individual's RA volume could not be calculated due to tissue damage and they were excluded from analysis.

\section{Statistical Analysis}

Data from each of the two experiments were analyzed separately, but in a similar manner. For body fat, wing chord, testis volume, testis weight, relative song nucleus volumes (HVC, RA, Area X), and telencephalon volume, we used one-way analysis of variance (ANOVA). To compare pretreatment and posttreatment samples between treatments groups for $\mathrm{T}$, body mass, and cloacal protuberance height, we used two-way repeated-measures ANOVA. The Tukey-Kramer HSD test was used for post hoc pairwise comparisons when appropriate. Prior to analysis, T, CP, gonad volume, HVC and Area X data were log transformed to meet assumptions of normality (Shapiro-Wilk W test) and homoscedasticity (Levene test). All statistical analysis was conducted in JMP 10.0 (SAS Institute Inc.).

\section{Results}

\section{Experiment 1}

Prior to implantation, treatment groups contained animals of similar size (wing chord: $\mathrm{F}_{1,14}=1.61, \mathrm{p}=0.225$ ) and condition (fat score: $\mathrm{F}_{1,14}=0.15, \mathrm{p}=0.705$ ). Body mass was also similar between groups and was unaffected by treatment during the experiments (table 1). Plasma T levels of captive animals did not differ between groups prior to implantation and were similar to nonbreeding baseline levels in free-living male $Z$. capensis (table 2) [Moore et al., 2004b]. Plasma T levels significantly increased in response to receiving $\mathrm{T}$ implants (tables 1,2 ). CPs grew significantly after $\mathrm{T}$ implantation and were larger than control CPs. Testis volume was greater in 
Table 1. Statistical comparisons of physiological and behavioral characteristics of male Z. capensis in experiments 1 and 2

\begin{tabular}{|c|c|c|c|c|c|c|}
\hline & \multicolumn{3}{|c|}{ Experiment 1} & \multicolumn{3}{|c|}{ Experiment 2} \\
\hline & $\mathrm{F}$ & d.f. & $\mathrm{p}$ & $\mathrm{F}$ & d.f. & $\mathrm{p}$ \\
\hline \multicolumn{7}{|l|}{$\mathrm{T}$} \\
\hline Treat & 169.7 & 1,14 & $<0.001$ & 52.6 & 3,17 & $<0.001$ \\
\hline Day & 118.4 & 1,14 & $<0.001$ & 772.5 & 1,17 & $<0.001$ \\
\hline Treat $\times$ day & 143.8 & 1,14 & $<0.001$ & 44.1 & 3,17 & $<0.001$ \\
\hline \multicolumn{7}{|l|}{$\mathrm{CP}$} \\
\hline Treat & 7.12 & 1,14 & 0.018 & 1.45 & 3,17 & 0.263 \\
\hline Day & 17.6 & 1,14 & $<0.001$ & 21.5 & 1,17 & $<0.001$ \\
\hline Treat $\times$ day & 12.2 & 1,14 & 0.004 & 5.41 & 3,17 & 0.009 \\
\hline \multicolumn{7}{|l|}{ Body mass } \\
\hline Treat & 0.08 & 1,14 & 0.307 & 2.27 & 3,17 & 0.117 \\
\hline Day & 0.47 & 1,14 & 0.503 & 5.96 & 1,17 & 0.026 \\
\hline Treat $\times$ day & 1.80 & 1,14 & 0.201 & 0.43 & 3,17 & 0.737 \\
\hline \multicolumn{7}{|l|}{ Activity } \\
\hline Treat & 0.47 & 2,14 & 0.502 & 1.34 & 3,17 & 0.294 \\
\hline Day & 4.06 & 2,13 & 0.043 & 0.01 & 2,16 & 0.985 \\
\hline Treat $\times$ day & 0.12 & 2,13 & 0.887 & 1.43 & 3,17 & 0.270 \\
\hline
\end{tabular}

Table 2. Testosterone concentrations and testis development in experiments 1 and 2

\begin{tabular}{|c|c|c|c|c|}
\hline \multirow[t]{2}{*}{ Treatment } & \multicolumn{2}{|c|}{ Plasma testosterone, $\mathrm{ng} / \mathrm{ml}$} & \multirow[t]{2}{*}{ Testis volume, $\mathrm{mm}^{3}$} & \multirow[t]{2}{*}{ Testis mass, $\mathrm{g}$} \\
\hline & before & after & & \\
\hline \multicolumn{5}{|l|}{ Experiment 1} \\
\hline Control & $0.23 \pm 0.04$ (a) & $0.19 \pm 0.03$ (a) & $3.4 \pm 1.2(\mathrm{a})$ & \\
\hline T-treated & $0.24 \pm 0.04(\mathrm{a})$ & $9.42 \pm 0.74(\mathrm{~b})$ & $78.1 \pm 18.0(\mathrm{~b})$ & \\
\hline \multicolumn{5}{|l|}{ Experiment 2} \\
\hline Control & $0.07 \pm 0.02(\mathrm{a})$ & $0.23 \pm 0.03(\mathrm{~b})$ & $4.3 \pm 1.5(\mathrm{a})$ & $0.06 \pm 0.02$ (a) \\
\hline T-treated & $0.10 \pm 0.03(\mathrm{a})$ & $8.56 \pm 0.90(\mathrm{c})$ & $78.4 \pm 11.0(\mathrm{~b})$ & $0.22 \pm 0.02(b)$ \\
\hline $\mathrm{T}+\mathrm{FLU}$ & $0.08 \pm 0.03(\mathrm{a})$ & $10.61 \pm 0.29(\mathrm{c})$ & $58.6 \pm 9.9(\mathrm{~b})$ & $0.14 \pm 0.02(\mathrm{a}, \mathrm{b})$ \\
\hline T+FLU+ATD & $0.05 \pm 0.01$ (a) & $12.61 \pm 0.80(\mathrm{c})$ & $29.8 \pm 16.4(\mathrm{~b})$ & $0.09 \pm 0.05$ (a) \\
\hline $\begin{array}{l}\text { Plasma testost } \\
\text { ter). Testis volum } \\
\text { ment. Values are } \\
\text { significantly diffe }\end{array}$ & $\begin{array}{l}\text { evels were mea } \\
\text { riments } 1 \text { and } \\
\text { t standard err } \\
\text { ukey-Kramer; }\end{array}$ & $\begin{array}{l}\text { orior to implant } \\
\text { estis mass (expe } \\
\text { hin each experin } \\
\text { 5). }\end{array}$ & $\begin{array}{l}\text { (before) and on the las } \\
\text { tts 2) were measured or } \\
\text { and data type, values }\end{array}$ & $\begin{array}{l}\text { day of treatment } \\
\text { the final day of tre } \\
\text { ot sharing a letter }\end{array}$ \\
\hline
\end{tabular}

birds implanted with $\mathrm{T}$ compared to controls (table 2). Activity levels were unaffected by treatment, but the activity level of all animals increased during the experiment (tables 1,3 ). No birds were heard singing in captivity during behavioral observations or at any other time during the experimental period. Telencephalon volume did not differ between treatment groups $\left(\mathrm{F}_{1,14}=0.13, \mathrm{p}=0.725\right)$. T-treated animals had larger relative HVC and RA volumes compared to controls (fig. 1a, b). Area X did not differ between groups (fig. 1c). 


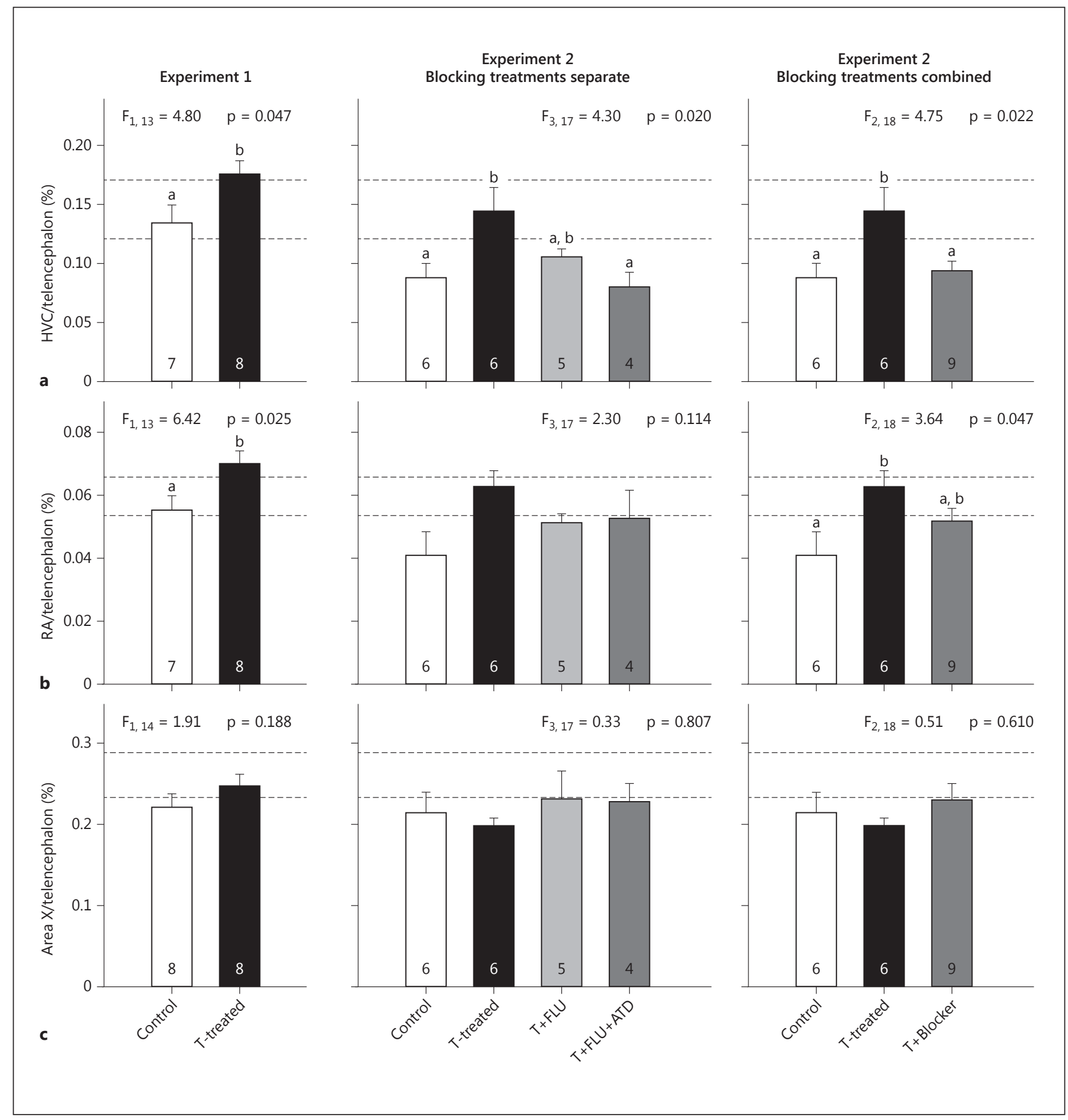

Fig. 1. Summary of captive $Z$. capensis relative SCN size [\% telencephalon of HVC (a), RA (b), and Area X (c)] in experiments 1 and 2. T-treated birds had larger HVC and RA but not Area X compared to nontreated (control) birds in both experiments. In experiment 2, the effect of T on HVC was blocked by the combined effect of androgen receptor antagonist FLU and the aromatase inhibitor ATD (T + Flu + ATD). In RA, neither FLU nor FLU + ATD treatment blocked the $\mathrm{T}$ treatment effect when the treatments were analyzed separately or when they were combined for analysis $(\mathrm{T}+$ blocker). Dashed lines are the mean relative SCN volumes of nonbreeding (lower line) and breeding (upper line) free-living $Z$. capensis from the same populations as those in this study [Moore et al., 2004]. One-way ANOVAs were used to investigate treatment effects followed by Tukey-Kramer pairwise comparisons when appropriate $(p<0.05)$. Bars sharing the same letter are not significantly different. Sample sizes are listed in the base of each bar. 
Table 3. Captive Z. capensis activity level during three observations (Obs) per experiment

\begin{tabular}{llll}
\hline Treatment & \multicolumn{4}{l}{ Activity, hops/min } \\
\cline { 2 - 4 } & Obs 1 & Obs 2 & Obs 3 \\
\hline Experiment 1 & & & \\
$\quad$ Control & $14.50 \pm 1.43$ & $16.00 \pm 2.44$ & $19.2 \pm 2.5$ \\
$\quad$ T-treated & $16.60 \pm 1.83$ & $16.60 \pm 1.45$ & $21.0 \pm 2.4$ \\
Experiment 2 & & & \\
$\quad$ Control & $26.20 \pm 3.75$ & $27.90 \pm 2.69$ & $23.2 \pm 3.5$ \\
T-treated & $23.80 \pm 3.46$ & $24.60 \pm 3.00$ & $28.0 \pm 1.4$ \\
T+FLU & $21.40 \pm 4.32$ & $23.20 \pm 5.37$ & $22.8 \pm 4.4$ \\
T+FLU+ATD & $19.70 \pm 4.06$ & $15.20 \pm 6.26$ & $17.9 \pm 4.2$ \\
\hline
\end{tabular}

There were no significant differences between treatments but activity significantly increased with time in experiment 1 (table 1 ).

\section{Experiment 2}

Prior to implantation, treatment groups contained animals of similar size (wing chord: $\mathrm{F}_{3,17}=0.79, \mathrm{p}=$ 0.518 ) and condition (fat score: $\mathrm{F}_{3,17}=0.42, \mathrm{p}=0.740$ ). Body mass was also similar between groups and was unaffected by treatment during the experiments (table 1). Plasma T levels of captive animals did not differ between groups prior to implantation and were similar to nonbreeding baseline levels in free-living male $Z$. capensis (table 2) [Moore et al., 2004b]. Plasma T levels significantly increased in all birds that received $\mathrm{T}$ implants regardless of concurrent ATD or FLU treatment (tables 1, 2 ). The CPs in the T+FLU group were similar to the CPs of the T-treated group and were significantly larger than those in the controls, but the CPs of T+FLU+ATD animals were not different from any other groups (table 1; Tukey-Kramer tests, $\mathrm{p}<0.05$; data not shown). Testis volume was greater in all treatment groups implanted with $\mathrm{T}$ compared to controls, independent of concurrent treatment with FLU or ATD (table 2). Testis mass was significantly greater in T-treated animals compared to controls and to T+FLU+ATD animals while testis mass of T+FLU animals were not different from any other groups (tables 1, 2). Activity levels were unaffected by treatment (tables 1,3). No birds were heard singing in captivity during behavioral observations or at any other time during the experiments. Because experiment 2 coincided with breeding in the local population in Quito, free-living rufous-collared sparrows could be heard singing in the distance (1-3/day; $>100 \mathrm{~m}$ away). Telencephalon volume did not differ between the treatment groups $\left(\mathrm{F}_{3,17}=0.53, \mathrm{p}=0.670\right)$. The T-treated animals had larg- er relative HVC volumes compared to controls, but treatment with FLU+ATD eliminated the effect of T on HVC while $\mathrm{T}+\mathrm{FLU}$ treatment did not differ from any of the groups (fig. 1a). There was no effect of treatment on either RA (fig. 1b) or Area X (fig. 1c) when the four treatment groups were analyzed. However, due to the limited sample size of both blocking treatments and the absence of any difference between them (comparing blocking treatments: $\mathrm{HVC} \mathrm{F}_{1,7}=3.54, \mathrm{p}=0.102 ; \mathrm{RA} \mathrm{F}_{1,7}=0.027$, $\mathrm{p}=0.873$; Area X $\left.\mathrm{F}_{1,7}=0.005, \mathrm{p}=0.944\right)$, the T+FLU and $\mathrm{T}+\mathrm{FLU}+\mathrm{ATD}$ groups were combined ( $\mathrm{T}+\mathrm{Blocker}$ ) to increase the sample size and the data were reanalyzed. In this new analysis, results from HVC were similar to the original analysis (fig. 1a), but there was a significant effect of treatment on RA (fig. 1b). Post hoc analysis revealed a similar effect of $\mathrm{T}$ on $\mathrm{RA}$ growth as in experiment 1 , but the $\mathrm{T}+$ Blocker animals were still not different from either the controls or T-treated animals. Also, similar to experiment 1 , Area $\mathrm{X}$ did not differ between any groups (fig. 1c).

\section{Discussion}

Here we have demonstrated that, similar to other song birds from higher latitudes, T stimulates growth of rufous-collared sparrow HVC and RA. However, unlike in many other song birds, T did not stimulate Area X growth. The growth of HVC and RA in the captive experiments was similar in magnitude to the growth between nonbreeding and breeding free-living rufous-collared sparrows (fig. 1) [Moore et al., 2004c]. These changes, however, occur in association with seasonal rainfall patterns rather than changes in day length. Thus, we have demonstrated that, similar to other songbirds, $\mathrm{T}$ stimulates growth of HVC and RA in equatorial rufous-collared sparrows.

We know of only one other free-living species that uses nonphotoperiodic cues to time SCN development, the subtropical rufous-winged sparrow (Peucaea carpalis, formerly in the genus Aimophila [DaCosta et al., 2009; Chesser et al., 2010]). In this species, gonadal development is stimulated by increasing photoperiod in the spring; however, luteinizing hormone and T remain low until gonadotropin-releasing hormone I release increases during the onset of temporally variable, late summer monsoon rains [Small et al., 2007, 2008a, b]. Concurrent with increasing plasma T, HVC and RA grow, and singing increases [Strand et al., 2007] despite declining day length. Together with the results from rufous-collared 
sparrows, the physiological regulation of song system neuroplasticity appears to be highly conserved in passerines regardless of the environmental cues that drive seasonal reproduction.

At the conclusion of both experiments, $\mathrm{T}$ levels in implanted birds were in the high physiological range for breeding rufous-collared sparrows. Although breeding $\mathrm{T}$ levels are often reported to be $2-4 \mathrm{ng} / \mathrm{ml}$ for this species [Moore et al., 2004c; Addis et al., 2010; González-Gómez et al., 2013], these values are population averages that can obscure individual high values [Hau et al., 2008; Williams, 2008]. Consistent with this, Moore et al. [2004b] found that the average $\mathrm{T}$ concentration for 35 breeding male rufous-collared sparrows was $4 \mathrm{ng} / \mathrm{ml}$. However, 5 of the 35 birds had $\mathrm{T}$ values between 10 and $14 \mathrm{ng} / \mathrm{ml}$, indicating the plasma $T$ levels of implanted birds were within the natural range for this species. It is possible that the silastic implants provided a higher dose of $\mathrm{T}$ during the early stages of the experiments [Fusani, 2008; Quispe et al., 2015]. However, a prior study on free-living rufouscollared sparrows, that used similar $\mathrm{T}$ implants (produced in the same lab), documented comparable plasma $\mathrm{T}$ concentrations $(10.5 \pm 1.5 \mathrm{ng} / \mathrm{ml})$ in birds sampled between 2 and 14 days after implantation [Moore et al., $2004 \mathrm{~b}$ ] suggesting that $\mathrm{T}$ levels were stable over the course of the experiments.

Results from experiment 2 indicate that T acts on HVC via conversion to estrogen, but it is unclear if it also acts directly through androgen receptors. In HVC, only the combined FLU+ATD treatment completely counteracted the effect of T while FLU treatment alone was not significantly different from any other group. Because of limited housing space, there was no ATD (without FLU) blocking group. Thus, we cannot exclude the possibility that the results from the FLU+ATD treatment were exclusively due to ATD blocking the estrogenic pathway, with no contribution from FLU's effect on androgen receptors.

RA grew in response to $\mathrm{T}$ treatment in both experiments, but unlike HVC and the testes, neither FLU nor FLU+ATD treatment eliminated the effect of T. In other species, RA and Area X growth are preceded by HVC growth [Tramontin and Brenowitz, 2000] and T does not appear to directly influence RA or Area X growth. Instead, $\mathrm{T}$ and its metabolites act through HVC, which projects to RA and Area X [Meitzen et al., 2007]. However, RA does contain androgen receptors and their activation appears to be necessary for HVC to stimulate growth of RA. In white-crowned sparrows, exposing RA neurons to FLU in one hemisphere of the brain prevent-

Testosterone and the Song System in a Tropical Bird ed an increase in soma size and spontaneous activity compared to the other hemisphere [Meitzen et al., 2007]. If androgen receptor activation in RA is also permissive for RA growth in rufous-collared sparrows, it is unclear why FLU treatment was not more effective at inhibiting RA growth.

T treatment also stimulated testes growth, a common occurrence in birds when $\mathrm{T}$ levels are high for an extended period of time [Hamner, 1968; Turek et al., 1976; Brown and Follett, 1977; Desjardins and Turek, 1977; Turek et al.,1980; Kumar and Kumar, 1990; Deviche et al., 2006]. The effect of $T$ on testes growth is likely due to a direct stimulatory effect via gonadal androgen receptors and estrogen receptors [Deviche et al., 2006, 2010] stimulating growth of the Sertoli cells. The effect of FLU and FLU+ATD treatments on gonadal weight mirrored their effects on HVC volume with FLU alone only having an 'intermediate' effect on testis weight compared to FLU+ATD. Along with an absent or reduced effect of FLU treatment on HVC and RA growth, this lack of a significant effect of FLU treatment suggests that androgen receptors either play a less important role in regulating T's influence in this tropical species or that FLU treatment was unable to completely block T's effects via androgen receptor binding.

In mammals, FLU treatment is more effective in castrated animals than in intact animals [Vagell and McGinnis, 1998]. This reduced effectiveness in intact mammals is thought to result from FLU blocking negative feedback of $\mathrm{T}$ at the hypothalamus and pituitary gland and the subsequent increase in endogenous androgen production [Viguier-Martinez et al., 1985; Mahler et al., 1998; Ohsako et al., 2003], which also occurs in reptiles [Tokarz, 1987] and birds [Soma et al., 1999b; Canoine and Gwinner, 2002; Moore et al., 2004a; Mougeot et al., 2005]. As a consequence, the higher T levels can reduce FLU efficacy by outcompeting it for androgen receptor binding [Tokarz, 1987; Chandolia et al., 1991]. This indicates that the chronic high $\mathrm{T}$ levels of the birds in this study may have decreased FLU's antiandrogenic effect and may account for the intermediate results in the T+FLU treatment.

Unexpectedly, we documented no treatment effect of $\mathrm{T}$ on Area X. Large individual variation, a small effect size, and relatively small sample sizes could have prevented changes in Area X from being detected. However, the volume of Area X in the captive birds was most consistent with entirely regressed prebreeding rufous-collared sparrows, whereas HVC and RA volumes were consistent with those of breeding birds [Moore et al., 
2004c], suggesting treatment simply had no effect on Area X.

After Area X growth was not detected in experiment 1 , three adjustments were made to the treatment protocol for experiment 2 to reduce the influence of potentially confounding factors on Area X growth. First, bringing free-living animals into captivity can cause chronic stress, particularly during the first few weeks of captivity [Cyr and Romero, 2009; Dickens et al., 2009; Mason, 2010], and elevated corticosterone can inhibit growth of the SCN [Newman et al., 2010]. For experiment 2, we held birds for over 2 months (3-4 times longer than for experiment 1) to better habituate them to captivity prior to treatment. Second, growth of Area X and RA in response to $\mathrm{T}$ treatment can lag behind growth of HVC and may take up to 20 days [Tramontin et al., 2000]. Although T treatment lasted for 21 days in experiment 1, the time course of nuclei growth is not known for this species, so treatment was extended to 27 days in experiment 2. Finally, sensitivity of the SCN to sex steroids may fluctuate seasonally [Soma et al., 1999a; Fusani et al., 2000; Strand et al., 2008; Fraley et al., 2010; Wacker et al., 2010]. Experiment 1 was concluded approximately 8 weeks prior to the initiation of reproduction in the bird's source population (Papallacta). For experiment 2, hormone treatment was timed to coincide with reproduction in the bird's source population (Pintag). The timing of experiment 2 also coincided with reproduction in the local, freeliving rufous-collared sparrow population where the birds were housed (Quito), thus increasing the likelihood that test animals were exposed to environmental cues associated with reproduction.

Despite the changes to the protocol, the results from experiments 1 and 2 were the same, which suggests that Area $\mathrm{X}$ growth is either (1) regulated by factors independent of $\mathrm{T},(2)$ regulated by factors in addition to $\mathrm{T}$ but which HVC and RA do not require, or (3) Area X growth is constrained by factors that do not constrain HVC and RA. It is possible that Area $\mathrm{X}$ requires more than 27 days of elevated $\mathrm{T}$ exposure to initiate growth. However, this would mean it lags more than a week behind RA which was developed by 21 days in experiment 1 . It is also possible that Area X growth was still suppressed by captive stress, while HVC and RA were not, but it is unclear why Area $\mathrm{X}$ would be more sensitive to chronic stress than HVC or RA.

The birds in both experiments did not sing. No instances of singing were recorded during behavioral observations, nor were the birds heard singing during any other point in the study. The aviary containing the study an- imals was situated next to the researcher housing and workspace. Bird song from more distant, free-living birds, including rufous-collared sparrows (experiment 2 only), could clearly be heard inside the facilities, thus it is unlikely that any significant amount of singing by the study animals could have gone undetected.

Some studies suggest that feedback from singing behavior is required for complete SCN growth [AlvarezBorda and Nottebohm, 2002; Ball et al., 2004; Sartor and Ball, 2005a, b; Alward et al., 2013]. However, similar to white-crowned sparrows [Brenowitz et al., 2007], we found that HVC and RA of rufous-collared sparrows grew to full reproductive volumes in the absence of auditory feedback from song. This finding does not exclude the possibility that there is a link between the absence of singing behavior and the lack of Area $\mathrm{X}$ growth, although any such link is entirely speculative at this time.

Male rufous-collared sparrows only sing during the breeding season [Moore et al., 2004c] and song is important in both territorial defense [Moore et al., 2004a; Addis et al., 2010] and courtship [Danner et al., 2011]. Strict seasonal expression of behavior is often under strong hormonal regulation [Hau et al., 2008; Lynn, 2008], but to date the only known effect of $\mathrm{T}$ on male behavior in this species is to reduce parental care [Lynn et al., 2009]. The absence of singing in T-treated males housed with other males is consistent with $\mathrm{T}$ manipulation having no effect on aggressive behaviors in free-living males [Moore et al., 2004a]. In other species, captive T treatment does stimulate singing in captive males housed alone or with other males [Tramontin et al., 1999; Dloniak and Deviche, 2001; Boseret et al., 2006; Strand et al., 2008; Meitzen et al., 2009], and T can stimulate singing in female songbirds which do not normally sing [Leonard, 1939; Kern and King, 1972; Hausberger et al., 2010; Lahaye et al., 2012; Madison et al., 2014]. At present, we have no evidence that $\mathrm{T}$ influences motivation to sing during male-male encounters, despite the birds having fully grown HVC and RA. The influence of $\mathrm{T}$ on courtship behaviors, including singing, has not been tested in this species, and T's influence on courtship behaviors cannot be inferred from the lack of changes in the aggressive response [Wiley, 2003; Lynn, 2008]. Until further studies are conducted, we cannot draw a strong conclusion about T's role in song complexity or in the motivation to sing in different social contexts.

While the environmental signals responsible are not clear, it is evident from this study that changes in T mediate the seasonal changes in HVC and RA volume in this tropical species and full development of these nuclei can 
be achieved without auditory feedback. However, other unknown factors that act independent of, or in conjunction with, $\mathrm{T}$ are required to stimulate changes in Area $\mathrm{X}$ volume. Finally, these data supply further evidence that while $\mathrm{T}$ and its metabolites have many similar physiological effects on tropical animals to those seen in more temperate species, the behavioral effects of T may be less pronounced or absent.

\section{Acknowledgements}

We are grateful to the Fundación Terra and Termas de Papallacta for allowing us to work on their properties. We are also grateful to Katherine Aldas Saltos, Ray Danner, Julie Danner, and Angelica Caiza for assistance in Ecuador. Funding was provided by an International Research Fellowship OISE-0602084 (T.W.S.), National Science Foundation grant IOB-0545735 (I.T.M.), NIH MH53032 (E.A.B.), and NIH R01 NS075331 (E.A.B.).

\section{References}

-Addis E, Busch DS, Clark AD, Wingfield JC (2010): Seasonal and social modulation of testosterone in Costa Rican rufous-collared sparrows (Zonotrichia capensis costaricensis). Gen Comp Endocrinol 166:581-589.

-Alvarez-Borda B, Nottebohm F (2002): Gonads and singing play separate, additive roles in new neuron recruitment in adult Canary brain. J Neurosci 22:8684-8690.

Alward BA, Balthazart J, Ball GF (2013): Differential effects of global versus local testosterone on singing behavior and its underlying neural substrate. Proc Natl Acad Sci USA 110: 19573-19578.

- Ball GF, Auger CJ, Bernard DJ, Charlier TD, Sartor JJ, Riters L V, Balthazart J (2004): Seasonal plasticity in the song control system: multiple brain sites of steroid hormone action and the importance of variation in song behavior. Ann NY Acad Sci 1016:586-610.

Bentley GE, Van't Hof TJ, Ball GF (1999): Seasonal neuroplasticity in the songbird telencephalon: a role for melatonin. Proc Natl Acad Sci USA 96:4674-4679.

- Bernard DJ, Bentley GE, Balthazart J, Turek FW, Ball GF (1999): Androgen receptor, estrogen receptor alpha, and estrogen receptor beta show distinct patterns of expression in forebrain song control nuclei of European starlings. Endocrinology 140:4633-4643.

- Boseret G, Carere C, Ball GF, Balthazart J (2006): Social context affects testosterone-induced singing and the volume of song control nuclei in male canaries (Serinus canaria). J Neurobiol 66:1044-1060.

-Bradshaw WE, Holzapfel CM (2007): Evolution of animal photoperiodism. Annu Rev Ecol Evol Syst 38:1-25.

Brenowitz E (2008): Plasticity of the song control system in adult birds; in Zeigler HP, Marler P (eds): Neuroscience of Birdsong, Cambridge, Cambridge University Press, pp 330-347.

-Brenowitz EA, Baptista LF, Lent K, Wingfield JC (1998): Seasonal plasticity of the song control system in wild Nuttall's white-crowned sparrows. J Neurobiol 34:69-82.

Brenowitz EA, Lent K, Rubel EW (2007): Auditory feedback and song production do not regulate seasonal growth of song control circuits in adult white-crowned sparrows. J Neurosci 27:6810-6814.
Brenowitz EA, Zeigler HP, Marler P (2004): Plasticity of the adult avian song control system. Ann NY Acad Sci 1016:560-585.

Brown NL, Follett BK (1977): Effects of androgens on the testes of intact and hypophysectomized Japanese quail. Gen Comp Endocrinol 33:267-277.

Canoine V, Gwinner E (2002): Seasonal differences in the hormonal control of territorial aggression in free-living European stonechats. Horm Behav 41:1-8.

-Cassone VM, Bartell PA, Earnest BJ, Kumar V (2008): Duration of melatonin regulates seasonal changes in song control nuclei of the house sparrow, Passer domesticus: independence from gonads and circadian entrainment. J Biol Rhythms 23:49-58.

-Chandolia RK, Weinbauer GF, Simoni M, Behre HM, Nieschlag E (1991): Comparative effects of chronic administration of the non-steroidal antiandrogens flutamide and Casodex on the reproductive system of the adult male rat. Eur J Endocrinol 125:547-555.

-Chesser R, Banks R, Barker F, Cicero C (2010): Fifty-first supplement to the American Ornithologists' Union check-list of North American birds. Auk 127:726-744.

Cyr NE, Romero LM (2009): Identifying hormonal habituation in field studies of stress. Gen Comp Endocrinol 161:295-303.

-DaCosta JM, Spellman GM, Escalante P, Klicka J (2009): A molecular systematic revision of two historically problematic songbird clades: Aimophila and Pipilo. J Avian Biol 40:206-216.

-Danner JE, Danner RM, Bonier F, Martin PR, Small TW, Moore IT (2011): Female, but not male, tropical sparrows respond more strongly to the local song dialect: implications for population divergence. Am Nat 178: 53-63.

Dawson A (2003): Photoperiodic control of the annual cycle in birds and comparison with mammals. Ardea 90:355-367.

Dawson A (2008): Control of the annual cycle in birds: endocrine constraints and plasticity in response to ecological variability. Philos Trans R Soc Lond B Biol Sci 363:1621-1633.

Desjardins C, Turek FW (1977): Effects of testosterone on spermatogenesis and luteinizing hormone release in Japanese quail. Gen Comp Endocrinol 33:293-303.
Deviche P, Hurley LL, Fokidis HB (2010): Avian testicular structure, function, and regulation; in Norris DO, Lopez KH (eds): Hormones and Reproduction of Vertebrates. New York, Academic Press, vol 1, pp 27-70.

Deviche P, Martin RK, Small TW, Sharp PJ (2006): Testosterone induces testicular development but reduces GnRH-I fiber density in the brain of the house finch, Carpodacus mexicanus. Gen Comp Endocrinol 147:167-174.

Dickens MJ, Earle KA, Romero LM (2009): Initial transference of wild birds to captivity alters stress physiology. Gen Comp Endocrinol 160: 76-83.

Dloniak SM, Deviche P (2001): Effects of testosterone and photoperiodic condition on song production and vocal control region volumes in adult male dark-eyed juncos (Junco hyemalis). Horm Behav 39:95-105.

-Fraley GS, Steiner RA, Lent KL, Brenowitz EA (2010): Seasonal changes in androgen receptor mRNA in the brain of the white-crowned sparrow. Gen Comp Endocrinol 166:66-71.

Fuchs E, Flügge G (2014): Adult neuroplasticity: more than 40 years of research. Neural Plast 2014;2014:541870.

-Fusani L, Van't Hof T, Hutchison JB, Gahr M (2000): Seasonal expression of androgen receptors, estrogen receptors, and aromatase in the canary brain in relation to circulating androgens and estrogens. J Neurobiol 43:254268.

Fusani L (2008): Endocrinology in field studies: problems and solutions for the experimental design. Gen Comp Endocrinol 157:249-253.

Gahr M (2001): Distribution of sex steroid hormone receptors in the avian brain: functional implications for neural sex differences and sexual behaviors. Microsc Res Tech 55:1-11.

Gahr M, Metzdorf R (1997): Distribution and dynamics in the expression of androgen and estrogen receptors in vocal control systems of songbirds. Brain Res Bull 44:509-517.

González-Gómez PL, Merrill L, Ellis VA, Venegas C, Pantoja JI, Vasquez RA, Wingfield JC (2013): Breaking down seasonality: androgen modulation and stress response in a highly stable environment. Gen Comp Endocrinol 191:1-12. 
Goymann W (2009): Social modulation of andro- Moore IT, Bentley GE, Wotus C, Wingfield JC gens in male birds. Gen Comp Endocrinol 163:149-157.

Hamner WM (1968): Photorefractory period of the house finch. Ecology 49:211-227.

-Hau M, Gill SA, Goymann W (2008): Tropical field endocrinology: ecology and evolution of testosterone concentrations in male birds. Gen Comp Endocrinol 157: 241-248.

Hausberger M, Henry L, Richard MA (2010): Testosterone-induced singing in female European starlings (Sturnus vulgaris). Ethology 99:193-208.

Kern MD, King JR (1972): Testosterone-induced singing in female white-crowned sparrows. Condor 74:204-209.

Kim YH, Perlman WR, Arnold AP (2004): Expression of androgen receptor mRNA in zebra finch song system: developmental regulation by estrogen. J Comp Neurol 469:535-547.

Kumar V, Kumar BS (1990): Effect of testosterone on testes, body weight and plumage regeneration in photorefractory male redheaded bunting Emberiza bruniceps. Indian J Exp Biol 28: 417-420.

Lahaye SEP, Eens M, Darras VM, Pinxten R (2012): Testosterone stimulates the expression of male-typical socio-sexual and song behaviors in female budgerigars (Melopsittacus undulatus): an experimental study. Gen Comp Endocrinol 178:82-88.

Leonard SLL (1939): Induction of singing in female canaries by injections of male hormone. Exp Biol Med 41:229-230.

Lynn SE (2008): Behavioral insensitivity to testosterone: why and how does testosterone alter paternal and aggressive behavior in some avian species but not others? Gen Comp Endocrinol 157:233-240.

- Lynn SE, Prince LE, Schook DM, Moore IT (2009): Supplementary testosterone inhibits paternal care in a tropically breeding sparrow, Zonotrichia capensis. Physiol Biochem Zool 82:699-708.

-Madison FN, Rouse ML, Balthazart J, Ball GF (2014): Reversing song behavior phenotype: testosterone driven induction of singing and measures of song quality in adult male and female canaries (Serinus canaria). Gen Comp Endocrinol 215:61-75.

-Mahler C, Verhelst J, Denis L (1998): Clinical pharmacokinetics of the antiandrogens and their efficacy in prostate cancer. Clin Pharmacokinet 34:405-417.

-Mason GJ (2010): Species differences in responses to captivity: stress, welfare and the comparative method. Trends Ecol Evol 25:713-721.

- Meitzen J, Moore IT, Lent K, Brenowitz EA, Perkel DJ (2007): Steroid hormones act transsynaptically within the forebrain to regulate neuronal phenotype and song stereotypy. J Neurosci 27:12045-12057.

-Meitzen J, Thompson CK, Choi H, Perkel DJ, Brenowitz EA (2009): Time course of changes in Gambel's white-crowned sparrow song behavior following transitions in breeding condition. Horm Behav 55:217-227.
(2006): Photoperiod-independent changes in immunoreactive brain gonadotropin-releasing hormone $(\mathrm{GnRH})$ in a free-living, tropical bird. Brain Behav Evol 68:37-44.

Moore IT, Bonier F, Wingfield J (2005): Reproductive asynchrony and population divergence between two tropical bird populations. Behav Ecol 16:755-762.

Moore IT, Perfito N, Wada H, Sperry TS, Wingfield JC (2002): Latitudinal variation in plasma testosterone levels in birds of the genus Zonotrichia. Gen Comp Endocrinol 129:13-19.

Moore IT, Wada H, Perfito N, Busch DS, Hahn TP, Wingfield JC (2004b): Territoriality and testosterone in an equatorial population of rufous-collared sparrows, Zonotrichia capensis. Anim Behav 67:411-420.

Moore IT, Walker BG, Wingfield JC (2004a): The effects of combined aromatase inhibitor and anti-androgen on male territorial aggression in a tropical population of rufous-collared sparrows, Zonotrichia capensis. Gen Comp Endocrinol 135:223-229.

Moore IT, Wingfield JC (2002): Reproductive cycles in equatorial populations of rufous-collared sparrows, Zonotrichia capensis. Integr Comp Biol 42:1281.

Moore IT, Wingfield JC, Brenowitz EA (2004c): Plasticity of the avian song control system in response to localized environmental cues in an equatorial songbird. J Neurosci 24:1018210185.

Mougeot F, Redpath S, Piertney S, Hudson P (2005): Separating behavioral and physiological mechanisms in testosterone mediated trade-offs. Am Nat 166:158-168.

-Newman AEM, MacDougall-Shackleton SA, An YS, Kriengwatana B, Soma KK (2010): Corticosterone and dehydroepiandrosterone have opposing effects on adult neuroplasticity in the avian song control system. J Comp Neurol 518:3662-3678.

Ohsako S, Kubota K, Kurosawa S, Takeda K, Qing W, Ishimura R, Tohyama C (2003): Alterations of gene expression in adult male rat testis and pituitary shortly after subacute administration of the antiandrogen flutamide. J Reprod Dev 49:275-290.

-Quispe R, Trappschuh M, Gahr M, Goymann W (2015): Towards more physiological manipulations of hormones in field studies: comparing the release dynamics of three kinds of testosterone implants, silastic tubing, time-release pellets and beeswax. Gen Comp Endocrinol 212:100-105.

Robertson BD, Hasstedt MR, Vandermeer CL, MacDougall-Shackleton SA (2014): Sex steroid-independent effects of photostimulation on the song-control system of white-throated sparrows (Zonotrichia albicollis). Gen Comp Endocrinol 204C:166-172.

Sartor JJ, Ball GF (2005a): Activity-dependent regulation of seasonal neuroplasticity in the song system in songbirds; in Dawson A, Sharp P) (eds): Functional Avian Endocrinology. New Delhi, Narosa Publishing House, pp 355-360.
Sartor JJ, Ball GF (2005b): Social suppression of song is associated with a reduction in volume of a song-control nucleus in European starlings (Sturnus vulgaris). Behav Neurosci 119: 233-244.

- Small TW, Sharp PJ, Bentley GE, Deviche P (2008b): Relative photorefractoriness, prolactin, and reproductive regression in a flexibly breeding sonoran desert passerine, the rufous-winged sparrow, Aimophila carpalis. J Biol Rhythms 23:69-80.

-Small TW, Sharp PJ, Bentley GE, Millar RP, Tsutsui K, Mura E, Deviche P (2008a): Photoperiod-independent hypothalamic regulation of luteinizing hormone secretion in a free-living Sonoran Desert bird, the rufous-winged sparrow (Aimophila carpalis). Brain Behav Evol 71:127-142.

Small TW, Sharp PJ, Deviche P (2007): Environmental regulation of the reproductive system in a flexibly breeding Sonoran Desert bird, the rufous-winged sparrow, Aimophila carpalis. Horm Behav 51:483-495.

-Smith GT, Brenowitz EA, Wingfield JC (1997): Seasonal changes in the size of the avian song control nucleus HVC defined by multiple histological markers. J Comp Neurol 381:253261.

Smith GT, Brenowitz EA, Wingfield JC, Baptista LF (1995): Seasonal changes in song nuclei and song behavior in Gambel's Whitecrowned Sparrows. J Neurobiol 28:114-125.

-Soma KK, Hartman VN, Wingfield JC, Brenowitz EA (1999a): Seasonal changes in androgen receptor immunoreactivity in the song nucleus HVc of a wild bird. J Comp Neurol 409:224236.

Soma KK, Sullivan K, Wingfield J (1999b): Combined aromatase inhibitor and antiandrogen treatment decreases territorial aggression in a wild songbird during the nonbreeding season. Gen Comp Endocrinol 115:442-453.

-Stevenson TJ, Small TW, Ball GF, Moore IT (2012): Variation in the gonadotrophin-releasing hormone- 1 and the song control system in the tropical breeding rufous-collared sparrow (Zonotrichia capensis) is dependent on sex and reproductive state. Gen Comp Endocrinol 178:1-7.

-Strand CR, Ross MS, Weiss SL, Deviche P (2008): Testosterone and social context affect singing behavior but not song control region volumes in adult male songbirds in the fall. Behav Processes 78:29-37.

Strand CR, Small TW, Deviche P (2007): Plasticity of the rufous-winged sparrow, Aimophila carpalis, song control regions during the monsoon-associated summer breeding period. Horm Behav 52:401-408.

Stutchbury BJM, Morton ES (2001): Behavioral Ecology of Tropical Birds. San Diego, Academic Press.

Thompson CK, Brenowitz EA (2005): Seasonal change in neuron size and spacing but not neuronal recruitment in a basal ganglia nucleus in the avian song control system. J Comp Neurol 481:276-283. 
Tokarz R (1987): Effects of the antiandrogens cyproterone acetate and flutamide on male reproductive behavior in a lizard (Anolis sagrei). Horm Behav 21:1-16.

Tramontin AD, Brenowitz EA (2000): Seasonal plasticity in the adult brain. Trends Neurosci 23:251-258.

-Tramontin AD, Hartman VN, Brenowitz EA (2000): Breeding conditions induce rapid and sequential growth in adult avian song control circuits: a model of seasonal plasticity in the brain. J Neurosci 20:854-861.

Tramontin AD, Smith GT, Breuner CW, Brenowitz EA (1998): Seasonal plasticity and sexual dimorphism in the avian song control system: stereological measurement of neuron density and number. J Comp Neurol 396:186-192.

- Tramontin AD, Wingfield JC, Brenowitz EA (1999): Contributions of social cues and photoperiod to seasonal plasticity in the adult avian song control system. J Neurosci 19:476-483.
Turek FW, Desjardins C, Menaker M (1976): Anti-gonadal and pro-gonadal effects of testosterone in male House Sparrows. Gen Comp Endocrinol 28:395-402.

Turek FW, Wolfson A, Desjardins C (1980): Testosterone treatment blocks the termination of the gonadal photorefractory condition in white-throated sparrows maintained on short days. Gen Comp Endocrinol 41:365-371.

Vagell ME, McGinnis MY (1998): The role of gonadal steroid receptor activation in the restoration of sociosexual behavior in adult male rats. Horm Behav 33:163-179.

Viguier-Martinez MC, Hochereau-de Reviers MT, Perreau C (1985): Effects of flutamide or of supplementation with testosterone in prepubertal male rats prenatally treated with busulfan. Eur J Endocrinol 109:550-557.

Wacker DW, Wingfield JC, Davis JE, Meddle SL (2010): Seasonal changes in aromatase and androgen receptor, but not estrogen receptor mRNA expression in the brain of the free-living male song sparrow, Melospiza melodia morphna. J Comp Neurol 518:3819-3835.
Wada K, Hayase S, Imai R, Mori C, Kobayashi M, Liu WC, Takahasi M, Okanoya K (2013): Differential androgen receptor expression and DNA methylation state in striatum song nucleus Area X between wild and domesticated songbird strains. Eur J Neurosci 38:26002610.

Wiley C (2003): Testosterone is correlated with courtship but not aggression in the tropical buff-banded rail, Gallirallus philippensis. Horm Behav 43:554-560.

-Williams TD (2008): Individual variation in endocrine systems: moving beyond the 'tyranny of the Golden Mean'. Philos Trans R Soc Lond B Biol Sci 363:1687-1698.

Wingfield JC, Meddle SL, Moore IT, Busch S, Wacker DW, Lynn S, Clark A, Vasquez RA, Addis E (2007): Endocrine responsiveness to social challenges in northern and southern hemisphere populations of Zonotrichia. J Ornithol 148:435-441. 